\title{
The 2010 General Elections in Mbeya Urban Constituency: Actors and Processes
}

\author{
Consolata R. Sulley ${ }^{1}$ \\ ${ }^{1}$ Faculty of History, Arts and Oriental Studies, University of Leipzig, Leipzig, Germany \\ Correspondence: Consolata R. Sulley, Faculty of History, Arts and Oriental Studies, University of Leipzig, \\ Leipzig, Germany. Tel: 491-521-406-0449: E-mail: consraph@yahoo.com
}

Received: August 23, 2012 Accepted: September 6, 2012 Online Published: November 29, 2012

doi:10.5539/jpl.v5n4p86 URL: http://dx.doi.org/10.5539/jpl.v5n4p86

\begin{abstract}
Elections are very important part of a democratic polity. They are means through which citizens choose their representatives. The 2010 general elections in Tanzania were unique in that there was stiff competition between the ruling and opposition parties. The Mbeya urban constituency is exemplary of such competitive politics. In this article, I examine the entire electoral process and actors in the constituency with a view to evaluate their impact on both electoral outcomes and democracy. I argue that overall the entire process went smoothly albeit some specific problems related to voter registration, inadequate institutional capacity in managing elections, corruption, polling, and tallying of votes. In some instances, these problems led to violence in the constituency.
\end{abstract}

Keywords: Tanzania, Mbeya, democracy, elections

\section{Introduction}

In a democracy, struggle for political office takes place through elections. That struggle essentially involves elites. However, elites are always the minority. Despite being the minority, they perform all political functions, monopolize power and enjoy the advantages that power brings. Indeed, they rule over the majority in line with their wishes and interests. It should be pointed out that in order to compete for power, elites normally struggle to design, shape and reshape the rules of the game and resources among themselves (Bratton \&Walle, 2007; Pinkney, 1997). This would mean that the elites who are relatively more powerful are likely to influence the rules of the game in their favour. When a group of elites dominates such rules, the outcome is usually an unfair competition.

African states and governments almost universally adopted one-party state immediately after gaining political power from colonial control. This state of affairs lasted for decades in most countries before the Huntington's "Third Wave" in 1990's. During this wave, the democratic transition from authoritarianism to democracy saw the domination of the process by ruling parties. They were the ones who laid down principles of transition and consequently the entire rules of the game were skewed in their favour. Olukoshi (1998) aptly argues that during transition in Africa, while opposition groups were kept awaiting to be invited to participate in the founding elections, the ruling elites set parameters for their participation. The outcome of such transition has in most cases been suffocation of political space by ruling parties to the detriment of opposition parties, civil societies and other social movements. In the transition literature, this phenomenon is commonly referred to as top down democratisation in which the ruling elites initiated and controlled the democratic process (Hyden, 1999).

Just like its African counterparts, Tanzania (Note 1) was under a one-party rule for about three decades. It got its independence on 9 December, 1961 from British colonial rule. In 1962 it became a Republic whereby a Republican constitution was formed giving immense powers to the president as both the head of state and government. Elections leading to independence were on a multiparty framework before the country decided to abolish all opposition parties and any other organised groups for the sake of national unity, nation-building and development. The move towards single-party started in 1963 when the first president of Tanganyika Julius Kambarage Nyerere announced to the ruling party's Executive Committee then Tanganyika African National Union (TANU) the intention that Tanganyika should be a one-party state on the above mentioned grounds. This led to the formation of a Committee whose recommendations led to one-party state in 1965. This went hand in hand with the formation of an Interim constitution of 1965 whose Article 3(1) stated that there should be one political party in the United Republic of Tanzania. 
Constitutionally, TANU was therefore the only party in mainland Tanzania while the Afro Shiraz Party (ASP) was in Zanzibar. As if that was not enough, in 1975 the party was given more legal powers trough Parliamentary Act No. 8 of 1975. The Act stipulated that "all political activities in Tanzania shall be conducted by or under the auspices of the party." Furthermore, "the functions of all organs of the state of the United Republic of Tanzania shall be performed under the auspices of the party." As can be seen, the effect of this Act was to weaken other government institutions that affect the formal checks and balance. In 1977 Tanzania became a constitutional one-party state after the merger of TANU and ASP to form one party, the Chama cha Mapinduzi (CCM). It adopted the permanent Constitution of the United Republic of Tanzania in the same year leaving the party's strength untouched.

After a period of about three decades, Tanzania ushered democratic transition in 1992. Like in many other African countries, the process was triggered off by both donors' pressure and internal struggles. Following the economic crises of 1970s, for example, the world financial institutions particularly the International Monetary Fund (IMF) and the World Bank, to which African countries sought refuge in addressing the crises, provided the Structural Adjustment Policies (SAPs) in which political and economic liberalisation were key conditions. The United States for instance attached liberalisation conditionality to any kind of assistance. Internally, authoritarian regimes suffered a great deal of legitimacy crisis mainly due to the failure of producing adequate goods and services to cater for the needs of their respective populations (Wunsch and Olowu, 1990).

The democratic transition in Tanzania was essentially a top down process. The ruling party, CCM unilaterally managed the transition politics in its favour. It is because of that Baregu (2003) has described the process as "a CCM controlled transition." As a starting point, the president (also the chairman of the ruling party) formed a commission popularly known as the Nyalali Commission following its chairman, the late Chief Justice Francis Nyalali to determine whether Tanzania should go multiparty system or remain a single party state. This commission, though controlled, did a commendable job towards multi-party politics (Shivji, 2006). To be sure, the Commission recommended for a completely new constitution that is spirited on multiparty philosophy, massive civic education to de-indoctrinate the values of the single party system, an independent and impartial electoral commission, repeal of 40 bad laws to mention but a few (United Republic of Tanzania (URT) report of the Presidential Commission on Single Party or Multiparty system, 1992). It is interesting to note that, while the ruling party accepted the general recommendation for the multiparty system, it was reluctant to implement important issues raised by the commission. This left multiparty system under the sole monopoly of the ruling party. Some observers have for that matter described the Tanzanian political system as a "dominant party system", "de facto one party state", or "authoritarian regime" (Liviga, 2009; Makulilo, 2008; Whitehead, 2009). This state of affairs has made opposition parties remain remarkably weak to perform their functions effectively both within and without formal decision making organs. For example, in the 1995 elections, a combined share of opposition popular votes was $38.2 \%$ leaving the ruling party with a share of $61.8 \%$. In the 2000 elections, opposition performance dropped to $28.3 \%$ of popular votes. The performance further dropped to $19.72 \%$ in 2005. It was in the 2010 elections that opposition electoral performance rose to $38.83 \%$ (National Electoral Commission (NEC) Reports, 1996; 2001; 2006; 2010). This instability in performance by opposition parties is one of the defining features of weakly institutionalised parties (Raphael, 2011). Although the rules of the game did not significantly change in favour of democratic electoral politics, the relatively handsome performance by opposition parties in the 2010 elections could partly be explained by the elite factionalism. This simply means that more than in any other time, religious institutions, trade unions, students, and some civil societies were indifferent with the ruling party. For example workers demanded for better pays, churches were against the "Kadhi's court" and the "Organisation of Islamic Conference (OIC)" agenda, students particularly those at the University levels demanded for assured loans, Muslims were divided, some defending CCM on its stand on the issues of "Kadhi's Court" and the "OIC" agenda while others were against the party for its failure to introduce those institutions. Above all, the general public had the feeling that the party failed to implement its slogan of "Better life to every Tanzanian" to the reality. Yet, the ruling party was also confronted by internal factionalism.

With the above backdrop, the intention of this article is to examine actors and processes in the 2010 general elections in Mbeya Urban Constituency with a view to evaluate their impact on both electoral outcomes and democracy. It starts by a brief review of the legal and institutional frameworks governing elections in Tanzania followed by methodological issues. The second part provides the socio-economic and political contexts of the constituency. The third part discusses actors and processes specific to the 2010 elections in the constituency. On one hand, such actors like political parties, candidates, the National Electoral Commission, the office of the Registrar of Political Parties, the Prevention and Combating of Corruption Bureau (PCCB), security force, the media and citizens will be analysed. On the other hand, processes such as the registration of voters, nomination 
of candidates, election campaigns, voting, vote counting and declaration of results will be discussed. The forth part provides concluding remarks.

\section{Legal and Institutional Framework for Elections in Tanzania}

Principal legislations that guide the conduct of multiparty politics in the country include but not limited to the Constitution of the United Republic of Tanzania (1977), the National Elections Act. No. 1 of 1985, the Political Parties Act No. 5 of 1992, and the Election Expenses Act No. 6 of 2010. As already stated, these and many other laws in the Republic were made basically in favour of the ruling party. Stakeholders have disputed them since the re-introduction of multipartism in 1992. Hence the Civic United Front (CUF) and Chama Cha Demokrasia na Maendeleo (CHADEMA) put the need for a "new constitution" as their priority policy agendas in their election manifestos during the 2010 elections.

Institutionally, the cited statutes create and vest power in the National Electoral Commission (NEC) as the sole authority in the management of elections. Since its formation in 1993, stakeholders, particularly opposition parties have argued that the NEC is a property of CCM. It is biased in favour of the ruling party mainly because of how it is constituted, its powers, resources and independence of its commissioners. Article 74(1) of the Constitution of the United Republic of Tanzania 1977 and Section 4A(1) of the Elections (Amendment) Act. No. 13 of 1990 empower the president of the United Republic (also the Chairman of the ruling party) to unilaterally appoint the commissioners of NEC. The president can also remove any commissioner from office without or with reasons. It is interesting to note that the same president is a candidate in a given election. This raises doubt on the impartiality of NEC. Besides, NEC does not have its own independent budget deliberated by the National Assembly something which is likely to undermine its independence (Tanzania Election Monitoring Committee (TEMCO), 1997; 2001; 2006). Again, Section 7 (1) of the Elections Act No. 1 of 1985 authorises NEC to use staff from local government authorities. The problem with this arrangement is that these staff serve dual loyalty, that is, to NEC and their appointing authority mainly the Central Government. In this regard, the independence and impartiality of NEC is highly compromised (Makulilo, 2009). Similarly, the Office of the Registrar of Political Parties is constituted just like NEC. Section $4(1 \& 2)$ of the Political Parties Act No. 5 of 1992 gives the president powers to appoint both the Registrar and Deputy Registrar of political parties. These may be removed from office by the president when it pleases him or her.

Yet, other authorities which are controversial to election management include the Regional Commissioners (RCs) and District Commissioners (DCs). These work hand in hand with District Executive Directors (DEDs), Ward Executive Officers (WEOs) as well as Village Executive Officers (VEOs). The RCs, DCs and DEDs are presidential appointees and have always been trusted cadres of the ruling party. While they serve as security authorities in their own jurisdictions, they at the same time promote the interests of CCM. According to CCM's constitution of 1977, these officials are supposed to sit as members in the CCM's security committees in their respective jurisdictions. Their role is normally to mobilise resources from state for the ruling party. Similarly, they mobilise supporters around all walks of life in favour of CCM and prevent them to both support and attend opposition parties' meetings.

In all multiparty elections of 1995, 2000, 2005, and 2010, these officials worked significantly to ensure the ruling party won. In the view of TEMCO, there is no way one would have expected a level playing field if these officials had not been detached from the party (TEMCO, 2006; 2010.)

Just like the aforementioned institutions, security forces play a significant role in managing elections. Their role is supposedly to ensure peace and order throughout the election period. However, following the fused relationships between the ruling party and the security forces during the one party system (1965-1992), the behaviour of security forces to work impartially is yet to be a reality (Mallya, 2006; Kamata, 2006; Makulilo, 2010). It should be noted that the Commander-in-Chief of all armed forces is the president. Being the chairman of the ruling party whose constitution [Article 15(1)] requires him or her to advance the interests of the party beyond anything else, gives him or her high chance to use the security forces to the advantage of his or her party. The police has worked in favour of CCM since the inception of multipartism (TEMCO, 1995; 2000; 2005). Similarly, the security committees headed by the RCs and DCs still favour the ruling party at the expense of opposition parties.

The media particularly the state ones are supposed to work impartially towards all parties and candidates as per Section 53 (1, $2 \& 3)$ of the Elections Act No. 1 of 1985. This is because they are run by tax payers' money. Practically, however, the ruling party has been enjoying a lion's share of coverage since the inception of multipartism. For example in its weekly reports from October 11 to 17, 2010, Tanzania Media Election Coverage (Synovate) observed that "CCM's coverage on Media continued to double that of any other political party, the 
gape was even more obvious during Radio Broadcasts as the party has been covered a lot more than in recent weeks". Over that period, CCM got 60,850 seconds, followed by CHADEMA which got 29,960 seconds and CUF 23,760 seconds (Synovate, 2010).

Lastly, the laws governing elections in Tanzania strictly prohibit the use of ethnicity, abusive language and corruption during elections. To be specific, section 9(1)(c) of the Political Parties Act. No. 5 of 1992 provides that "no political party shall qualify for provisional registration unless "its membership is voluntary and open to all the citizens of the United Republic without discrimination on account of gender, religious beliefs, race, tribe, ethnic origin, profession or occupation"(emphasis mine). Yet, the Election Expenses Act stipulates "provisions for the funding of nomination process, election campaigns and elections with a view to controlling the use of funds and prohibited practices in the nomination process, election campaigns and elections, to make provisions for allocation, management and accountability of funds and to provide for consequential and related matters" (emphasis mine). The prohibited practices include in this regard ethnic politics, corruption and bribery among others. Despite the existence of laws, these practices have been characteristic features of Tanzanian politics.

\section{Methodology}

Information used in this article was collected during the 2010 elections (Note 2) through the observation of various electoral processes such as campaigns, voting, vote counting and declaration of results. Another technique was interviews. Interviews were conducted with a wide range of actors. These were National Electoral Commission (NEC), Registrar of Political Parties' Office, Prevention and Combating of Corruption Bureau (PCCB), political parties both participating and non-participating parties, and candidates. All parliamentary candidates from participating parties and some council candidates were interviewed. The interviews apart from enabling the observer to acquire information on the already conducted processes of registration and nomination of candidates, they also facilitated to get other useful facts on the general conduct of election. Data from documents was also useful in this article. Documents such as observation reports, parliamentary Acts, statutes, speeches, election reports, constitutions and government reports were used. Documents usually provide official position of institutions over a long period of time and can easily be accessed.

\section{Mbeya Urban Constituency: Political, Social and Economic Context}

Mbeya Urban constituency is one of the eleven constituencies in Mbeya region. It is located in the city centre of Mbeya. Administratively, the constituency is divided into thirty six (36) wards. According to the 2002 Population and Housing Census in Tanzania the population of Mbeya Urban constituency is 266,422. Geographically, Mbeya region is located in the southern highlands of Tanzania surrounded by mountains. The City is generally considered a highland characterized by moderate climate and sufficient rainfall. The climatic condition is very good for agriculture where crops like maize, paddy, banana, potatoes, tea and coffee grow well. Major economic activities in the Constituency include commerce and trade, agriculture and livestock keeping, small-scale industrial production and service provision e.g. transport, hotel, medical services, and civil service (Mbeya City Council Investment Profile 2010). It is estimated that 33.3\% of City residents depend on agriculture for their livelihood; $21 \%$ are employed in the public sector which is mainly service provision and $43.4 \%$ are engaged in the informal sector which is mainly small scale production, petty trade and selling of agricultural crops and 2.3\% home works and others (Mbeya City Council Investment Profile, 2010).

Politically, the constituency has been a home of competition between the ruling party, CCM and opposition parties especially the National Convention for Reconstruction and Reform (NCCR-MAGEUZI) and Chama cha Demokrasia na Maendeleo (CHADEMA).The presence of 10 political parties could be traced in the constituency. These are, CCM, CHADEMA, Civic United Front (CUF), Tanzania Labour Party (TLP), NCCR-MAGEUZI, African People' Progressive Party of Tanzania (APPT-MAENDELO), Tanzania Democratic Alliance (TADEA), Democratic Party (DP), United People's Democratic Party (UPDP), and Sauti ya Umma (SAU). Nonetheless, these parties differ in terms of their strengths. Generally, CCM is the strongest party in terms of resources both material and human while opposition parties are in general handicapped.

Several issues are at the apex to explaining the political context of Mbeya urban constituency. First and for most is ethnicity factor which splits the constituency into two antagonistic ethnic groups of Nyakyusa and Safwa. The former consists of the learned and wealthy and they are the majority. The latter is the minority and considers itself as the marginalised. In 2000 and 2005 the Safwa candidate through CCM was elected a member of parliament on among others, ethnic grounds. In that election, Safwa candidate Mr. Benson Mwailugula Mpesya campaigned to the Safwa that they are being marginalised because there is no spokes person representing their interests in the government. He convincingly influenced people and finally won the two general elections of 2000 and 2005. Yet, the candidate was alleged to have used corrupt strategies by slaughtering cows and cooked 
rise for people in order to attract their votes. This strategy was supposedly used in 2010 elections as well. (Note 3)

In the 2010 general elections however, the situation was different since the Safwa candidate from CCM competed with the Kinga from CHADEMA. Apart from claims that the CCM candidate underperformed in his two terms, ethnicity is not the major factor that explains electoral results that gave victory to a person who does not belong to either of the two tribes. In this regard, several other factors can also be taken on board to explaining this year's election. The first is the personal celebrity of the CHADEMA candidate who is a famous Hip hop artist Mr. Joseph Mbilinyi (famously known as Mr. Sugu, Mr. II or II Proud) and his strength in singing songs that are critical to the government. Among others, the candidate capitalised his celebrity by singing on police brutality, human rights and development. Anchored in this spirit, most people were convinced to have found their spokesperson in the parliament. Second is the party's popularity built by its presidential candidate Dr. Wilbroad Peter Slaa by being very vocal against cases of grand corruption such as the Richmond and Bank of Tanzania's saga that sparked top leaders of the fourth union government like the then prime minister Edward Lowasa who resigned of being accused of corruption in Richmond saga in 2007. The phenomenon gained momentum and is popularly known as "Ufisadi".

Third is what I could call a "wave of change" that was unique to the 2010 election in Tanzania. My close observation was that people wanted "change" without necessarily caring about the outcome of the change and that they seemed tired of always being under CCM.

The sentiments of change were mostly spearheaded by the youth who unlike in previous general elections, showed up in large numbers in campaign meetings and polling. This led to victories of a number of opposition candidates not only in Mbeya but also in many other constituencies. It should be noted that youths demonstrated not to be the strong supporters of the ruling party. This was evidenced by their poor attendance in CCM campaign meetings. In CCM meetings more elders especially women attended in large numbers. This fact is well acknowledged by CCM itself. In my telephone interview with one of the CCM's youth wing (UVCCM) members in Mbeya it was noted: "CCM is a strong party, we must win in this election. This is because most supporters of opposition parties are youths who are the "wahuni"(Crooks) and they normally do not turn out to vote. CCM on the other hand is highly supported by the elders and most particularly by women who normally turn out to vote. We keep telling people about this fact". (Note 4). This campaign strategy, to my observation encouraged the youth even more rather than discouraging them to support the opposition. Failure of CCM to implement its 2005 election promises also played a significant role in explaining the oppositions' performance and CCM's failure in many constituencies.

The fourth factor would be factions within CCM. This was created during nominations within the party. CCM has a tradition of nominating its candidates through elections by party members. It was claimed that some of those who failed in the nomination campaigned against the nominated candidates. This fact was even more evident in Mbeya Urban Constituency. It started during CCM's nomination for the member of the National Executive Committee (NEC) of the party. In that nomination, the perceived 'king' of the Nyakyusa ethnic group Prof. Mark James Mwandosya then minister for Water and Irrigation competed with Thomas Mwang'onda the son of the then Director of Tanzania Intelligence and Security Service (TISS) Mr. Cornel Apson Mwang'onda (also Nyakyusa). In that competition, the Nyakyusa gave victory to their king Mark Mwandosya. After failing in NEC's competition, Mr. Thomas competed in CCM parliamentary candidate nominations in Mbeya Urban Constituency. Although he competed with the Safwa and incumbent Mr. Benson Mwailugula Mpesya, he could not win. Explaining reasons for his failure, the CCM's youth wing (UVCCM) member (Note 5) said he was punished by the Nyakyusa because he wanted to remove their 'king' from power. This, according to him, resulted to CCM having a weak candidate thereby loosing in election. The fractions within CCM was also noted by Mama Salma Kikwete when she came to campaign for Mr. Jakaya Mrisho Kikwete CCM presidential candidate and her husband. She emphasised that they should not entertain factions since they are detrimental to the party. (Note 6).

\section{Actors and Processes}

An examination of election processes and actors is done by identifying the processes and actors involved in each process. Four processes and their actors are considered in this part. These are voter registration, nomination of candidates, election campaigns, voting, vote counting, and declaration of results. Each is examined in turn.

\subsection{Registration}

Registration of voters is a prerequisite stage towards a general election in Tanzania. This is particularly so because no voters no election. In this stage, citizens, parties, the media, and the NEC are the most immediate 
actors towards its effect. In Tanzania people register in what is referred to as the Permanent National Voters' Register (PNVR). Article 5(1) and Section 10(1) of the Constitution of the United Republic of Tanzania and the Elections Act No. 1 of 1985 respectively stipulate the eligible person to register and to vote to be one who has attained the age of eighteen years and a citizen of Tanzania. It is imperative that one registers in the Voters Register for s/he to be able to vote. In order for this exercise to be effectively achieved, the NEC normally has to provide voters education to sensitize citizens the importance of registering and voting. It is worth acknowledging that NEC has done commendable job. According to NEC, about 20 million people were registered national wide for the 2010 general elections. In Mbeya Urban Constituency 174,854 people were registered until the last upgrading exercise in July 2010. There were only three upgrading exercises done in the constituency (Note 7). Despite the commendable job done by NEC, there were still problems on registration.

Firstly, many people were still not registered because of limited time specified for registration and upgrading of registration by NEC. About 500 people who showed up after the third upgrading exercise were estimated to have not been registered (Note 8). This, I argue is not by default but by design because there was no prescribed time for that exercise. Instead it was the discretion of the Returning Officer who represents NEC at constituency level to decide. Section 5(1) of the Elections Act No. 1 of 1985 states categorically that "The Commission shall be responsible in setting time and update of registration of voters in every polling district within the constituency".

Secondly, much was and is needed to be done on voter education. Respondents from political parties (Note 9) commented that NEC did nothing in providing voter's education. This, according to them, is a deliberate measure because CCM and its government benefit a great deal from the ignorance and poverty of many Tanzanians. In his press conference on 15 October, 2010 at Mbeya Peak Hotel CUF's presidential running mate Mr. Haji Duni Haji vehemently maintained: " $\mathrm{CCM}$ and its government use ignorance and poverty as their political capital. He furthered that if you want to rule easily, increase ignorance/illiteracy and poverty among your people. This is what CCM does." The government also deliberately provide inadequate funds to NEC to provide national wide civic education (TEMCO, 1997; 2001; 2006).

Yet, anomalies that rise questions with regards to the registration of voters were observed. Examining the number of eligible voters in the constituency, different figures were given. The first was 174,854 given by the District Registration Officer (DRO). This according to the DRO was obtained after the last upgrading exercise. However, the Returning Officer (RO) (Note 10) gave a different figure which was a total of 177, 402 an increment of 2548 voters. When asked why is the figure different from the one given by the DRO, the RO gave interesting explanations: One, he said the DRO did not know the correct number. Secondly, he said the DRO gave the figure of those who registered in the 2009 civic elections. As it can be seen, explanations by the RO leave a lot to be desired. In the first place, in the 2009 civic elections the PNVR was not used. It would therefore be impossible for the DRO to confuse between the two. In the second place, the DRO noted clearly amongst the challenges that the PNVR face to be the discrepancy between the number in the constituency's register books and those coming from the NEC. For that matter therefore they normally take the books coming from NEC since they are always bigger in number than those in the constituency.

It can be asked, where does the NEC get its data to produce the books? If it produces them from the data in the respective areas, why should there be discrepancies? As if that was not enough, other different figures were noted in the process of vote counting where by a total number of registered voters in the constituency was 177,468 for parliamentary results and 177, 949 for presidential results (NEC Mbeya Urban Constituency, 2010). It is worth interrogating whether or not NEC registers voters according to the type of election. If not, it is then inconceivable for the number of registered voters to differ according to the type of election. It is therefore plausible to presume that there is an open agenda of vote rigging through what I call "Ghost Voters".

Another interesting issue on the registration of voters is the irresponsibility of NEC to produce books that reflect all those who registered. I call it irresponsibility because a substantial number of people in the constituency could not find their names in the PNVR, others could not see their voters card numbers and yet others could not see their pictures. It should be noted that all with these problems could not vote. This problem will be dealt with in more details in the analysis of the voting process.

\subsection{Nomination}

The second process is the nomination of candidates. In this stage, political parties, citizens, NEC, PCCB and the office of the registrar of political parties were directly or indirectly involved. A total number of eight parties participated in the 2010 election. These were CCM, CHADEMA, NCCR-MAGEUZI, CUF, APPT-MAENDELEO, TLP, UPDP, and DP. Each of which used different modalities in nominating candidates. 
Parties which demonstrated clear and elaborate procedures of nomination or democratic model are CCM, CUF and APPT-MAENDELEO.

This is owing to the fact that the candidates from the three parties filled nomination forms and then campaigned to party members. For the case of parliamentary candidates, party members voted at the district and for councillors, members voted at the ward level. The special seats candidates were being voted for in the party women wings of all parties. CHADEMA and NCCR-MAGEUZI operated a semi democratic model of nomination. Aspirants for the parliamentary post filled forms. A general meeting involving ten members from each ward was held to elect the candidate as the first election. The results were discussed by what is called "kamati ya utendaji" (Party's Committee) for comments and finally the names of the aspirants were brought to the national level for selection and approval. For the case of councillorship, the district party leadership was the final nominating authority. The special seats post were elected by the women wings of the parties and the names were authorised from the national level for the case of Member of Parliament special seat post and from district level for councillor's post. The Tanzania Labour Party (TLP) operated a non-democratic or top down nomination model. This is because no voting was involved and the party district administration was the final nominating authority. UPDP and DP operated neither democratic nor undemocratic models since candidates for these parties volunteered themselves and the party leadership of the respective parties authorised them. Note that, the two parties had only a parliamentary candidate without a single council candidate. Of importance to note is that unlike CCM which had prescribed procedures and standards for the nomination which were done practically, most of other parties described them on papers and could not be followed practically.

In general terms, the nomination process went smoothly albeit some problems. These were related to corrupt practices in the nomination. CCM was the most alleged party to have been using this ill strategy in its nomination. This was evidenced by the Prevention and Combating of Corruption Bureau (PCCB) (Note 11) and the office of the Registrar of Political parties (Note 12). In Mbeya, most allegations of corruption in the nomination process in particular and election in general were heard and reported during CCM's nomination period. According to the officers this was predominantly done by the ruling party CCM. This may be the case because CCM has much resource base (sometimes it uses state resources to corrupt voters) as opposed to the opposition parties. This position is also held by the Institute of Development Studies of the University of Dar es Salaam in its survey on Corruption and Election in the 2009 Civic Elections when CCM was rated as the most corrupt party.

Table 1. Respondents' Opinions on the most Corrupt Political Parties by Regions in percentage

\begin{tabular}{cccccccc}
\hline \multirow{2}{*}{ Region } & \multicolumn{7}{c}{ Most Corrupt Political Parties } \\
& CCM & CUF & CHADEMA & NCCR & TLP & I Don't Know & No Response \\
\hline Manyara & 57.1 & 11.4 & 5.7 & 0.0 & 0.0 & 8.6 & 17.1 \\
Arusha & 48.6 & 0.0 & 13.5 & 0.0 & 0.0 & 10.8 & 27.0 \\
Dar es & 100.0 & 0.0 & 0.0 & 0.0 & 0.0 & 0.0 & 0.0 \\
Salaam & & & & & & 0.0 & 50.0 \\
Tanga & 50.0 & 0.0 & 0.0 & 0.0 & 0.0 & 0.0 & 41.1 \\
Kilimanjaro & 31.0 & 0.0 & 3.4 & 3.4 & 0.0 & 20.7 & 23.1 \\
Morogoro & 50.0 & 3.8 & 11.5 & 0.0 & 0.0 & 11.5 & 36.0 \\
Dodoma & 48.0 & 0.0 & 8.0 & 0.0 & 4.0 & 4.0 & 30.6 \\
Total & 49.5 & 2.7 & 7.0 & 0.5 & 0.5 & 9.1 & \\
\hline
\end{tabular}

Source: University of Dar es Salaam, Institute of Development Studies (IDS), 2010).

It was acknowledged by the PCCB officer that detecting corrupt practices in the nomination was quite a tedious exercise. For example, the office was informed that corruption was going on in a certain place where people were given foods, drinks, money as well as clothes. They went to the place only to find that it was a wedding ceremony going on. Although the officer noted the presence of cases of corruption, she could not give the reported cases claiming them to have still been under investigation. The other major challenge noted by the 
officer was manpower problem. There could be corrupt practice going on somewhere but it becomes difficult for them to act because of the manpower as well as means of transport shortages.

The office of the registrar of political parties is one of the responsible actors in this stage as well. It is specifically so because of its responsibility in overseeing the implementation of the Election Expenses Act No. 6 of 2010 whose main objectives are among others to control the use of funds and prohibited practices such as corruption in elections. The office is however faced with even bigger challenges than those of the PCCB. This is because it works through the PCCB which is in itself handicapped resource wise as explained earlier. The office is also highly concentrated in its headquarters Dar es Salaam. For purposes of the 2010 elections for instance the office established a Southern Highlands zonal office in Mbeya whereby literally two officers oversaw the implementation of the Act in four regions of Mbeya, Iringa, Rukwa and Ruvuma constituting the zonal office. It is a shaggy dog story in my view for the two officers to work in the four regions and expect them to be effective in detecting and dealing with corrupt practices.

The weaknesses of the two offices in preventing and controlling corruption in election have significantly been commented on by various stakeholders (Note 13). The political parties both the ruling and the opposition argue categorically that the offices are not effective due to inadequate resources both human and material and that they have been reluctant to act immediately when they are being informed about the corrupt practices. The CCM parliamentary candidate (Note 14) remarked that the PCCB acts subjectively since they act in some individual's directives and not by the requirement of the law. He added that the office is very slow in taking actions. The unwillingness of PCCB was also acknowledged by the CHADEMA parliamentary candidate (Note 15) by arguing that CCM parliamentary candidate slaughtered cows and cooked rise to attract voters. This has been his practice and no action was taken by the PCCB office. Additionally, when the core member of CCM youth wing Mr. Ridhwan Kikwete held what was called party internal meeting (Note 16) with the youth in Mbeya, he was alleged to have given to the youth money and bicycles to enable them buy voters cards. If one manages to get 200 cards s/he was promised a motor circle. This allegation was also heard from many ordinary citizens. Regrettably, none of the responsible institutions took action against the allegations.

Besides, the two offices are the instrument of the ruling party (Note 17) and in most cases are afraid of CCM and its government. This was evidenced by the two officers themselves that threats from CCM and its government are the orders of the day. The PCCB officer while making reference to her former working place in Singida argued that one of the women's special seat councillor told them after being caught of bribing people that: "why are you arresting me, even Kikwete (Note 18) wins using this strategy. After all, it is us who employed you".

The Regional Commissioner of the place told the PCCB officers to leave the CCM people, otherwise they would be in trouble. This fact can also explain why the CCM presidential candidate Mr. Jakaya Mrisho Kikwete campaigned for his party members who were already accused of corruption in elections. CUF parliamentary candidate (Note 19) argued vigorously that PCCB is an instrument of the president. He gave the example of Mr. Fred Mwakelebela who was accused of corruption during CCM's party nominations in Iringa. Surprisingly, the president told the public that he was a clean person and insisted for his election.

A close examination of these weaknesses suggests that the main problem lies not only on the management authorities but also to the parties, candidates and citizens. This is because there is already a norm that is in people's minds that they cannot cast their votes without being bribed. This habit was legalised by the ruling party CCM and its government. In 2000, the Takrima Law was enacted as an amendment to the Elections Act. No. 1 of 1985 i.e. Act. No. 4 of 2000, and thus Section 98(2) read: "anything done in good faith as an act of normal or traditional hospitality, shall be deemed not to be treating."

Subsection (3) of the same section provided further that "normal or ordinary expenses spent in good faith in the election campaign or in the ordinary cause of election process shall be deemed not to be treating, bribery or illegal practice." What is called traditional hospitality left to the minds of people a legacy that they must give or be given something to offer or to be offered a vote. This makes corruption systemic and hence difficult to fight.

\subsection{Campaigns}

Campaigns are very crucial part in democratic elections. This is the avenue where parties and their candidates sell their policies and strategies in order to be elected in office. It is also the avenue where electorate can choose candidates whom they think best represent their interests. If not properly managed and conducted however, campaigns can lead into chaos and sometimes in the choice of people based not on their abilities to represent people's interests but on the basis of misguided propaganda and corruption. Specific actors in this process are parties, candidates, citizens, media, PCCB and NEC. Most campaigns in Mbeya urban constituency were conducted in accordance with the requirements of electoral laws. A very commendable job was done by the 
police force by covering on equal basis all campaigns. This was acknowledged by all political parties from the opposition camp as well as the ruling party CCM. Notwithstanding this good achievement, irregularities and limitations were noted in the campaign process.

The first was resource limitation. Of the eight participating parties in the constituency, only three parties that is CCM, CHADEMA and CUF could conduct public campaigns. Nonetheless, CUF could not hold some rallies because of resource constraint. The NCCR-MAGEUZI parliamentary candidate for instance informally withdrew from contesting and decided to support CUF candidate. When asked for reasons for his withdrawal, the NCCR-MAGEUZI candidate (Note 20) stated that apart from deciding to support CUF, he was constrained in terms of resources. The candidate was using CUF parliamentary campaigns to also campaign for himself as council candidate of Ghana ward through NCCR-MAGEUZI. Other parties and candidates who could not publicly campaign were UPDP and DP. The UPDP parliamentary candidate (Note 21) declared to have been using house-to- house campaign strategy because her party and herself did not have funds to support her campaigns. CHADEMA council candidate for Ruanda ward also declared to have been using house-to-house campaign because of the same reason. Most candidates and parties resorted to this strategy towards the end of campaigns as a result of limited funds. One of them was APPT-MAENDELEO council candidate for Iyunga ward.

CCM was not affected by resource problem. This owes to reasons which are clear. One was the use of government institutions and officials to foster campaigns of the ruling party CCM at the expense of opposition parties. A good example of a government institution used was Mbeya City Council which passed a regulation that if one wants to advertise to the public his/her business or party ideology using placards then one needs to pay 30, 000 Tanzanian shillings per day. This was directly or indirectly favouring the ruling party which without a moment's hesitation has strong resource base unlike opposition parties. Parties and candidates from opposition who wanted to use this strategy could not manage. For instance the UPDP parliamentary candidate who did not campaign publicly wanted to use the strategy but she could not afford the cost.

District Commissioners (DCs) and Ward Executive officers were also used to advance the interests of the ruling party CCM. As noted earlier, these are members of NEC in their respective areas. The DC in Mbeya Urban using government car, escorted campaign motor cage of Mama Salma Kikwete on 19 October, 2010 when she came to campaign for CCM presidential candidate Mr. Jakaya Mrisho Kikwete, her husband. In addition, the DC was allegedly accused of holding meetings and urge people not to elect young candidates. This statement though an accusation, had an ill intention to campaign against CHADEMA candidate who was the youngest. In another incidence, one of the campaign team's member of CCM council candidate in Itiji ward referred to the Ward Executive Officers (WEO) at the meeting (Note 22) as the source of CCM's victory. This clearly illustrates that $\mathrm{CCM}$ enjoys from state resources to foster its victory. This should not be surprising because they are historically owned by the ruling party and its government.

The second problem observed during campaigns was the use of abusive language mainly by CCM candidates and leaders towards the opposition parties particularly CHADEMA. In Mbeya Urban constituency for example, CCM parliamentary candidate Mr. Benson Mwailugula Mpesya heavily used abusive language in most of his campaigns instead of campaigning to the electorate his party manifesto. The candidate in most cases referred to CHADEMA parliamentary candidate as the "Mhuni, anavaa mlegezo, amevaa mewani ya mbao hivyo haoni CCM imeifanyia nini wananchi". CHADEMA wanasema eti Benson analala bungeni, kachoka. Kama nimechoka ningeweza kuzaa na mke wangu? Anayejua nimechoka ni mke wangu na si mtu mwigine (Note 23). The CCM candidate usually starts rapping imitating the CHADEMA candidate at the beginning of his campaigns. Of interest to note however, is that, these defamatory statements instead of changing people's support for CHADEMA it instead increased it.

Irregularities in campaign time observance were also another weakness. In general terms most campaigns were held within the time limit of not longer than $18.00 \mathrm{pm}$. However, some parties and candidates did not observe this limit. Good examples are the Civic United Front (CUF) which in its parliamentary candidate's campaign Mr. Prince Gwamaka Mwaihojo on 9 October, 2010 held his campaign at Iyela ward. Interestingly, the meeting was supposed to start at $14.00 \mathrm{pm}$. However, the candidate arrived at 17.45. He started addressing the meeting at 18.05 and the meeting was closed at $18.45 \mathrm{pm}$. Another interesting observation was that the meeting was not covered in terms of security and the attendance was very poor. Similarly, on 25 October, 2010 the same candidate held his campaigns at Ghana ward. The meeting was closed at 18.15 but the music continued until 18.25. The two police men at the meeting cautioned them that if anything happened afterwards they would be less concerned. 
The second meeting was held on 4 October, 2010 when Dr. Wilbroad Peter Slaa, CHADEMA presidential candidate was supposed to hold his campaign rally. However, the candidate's Helicopter had problems thereby making him come late for the meeting. The candidate arrived at 17.58. There was no sound system for the candidate to address the meeting. It was not until 18.21 when the system arrived. The candidate greeted the mass at 18.30 by just telling them that he is always at the fore front of telling Kikwete CCM presidential candidate for going against time. He promised the mass that he would accomplish his campaigns in Mbeya on $30^{\text {th }}$ October 2010 and the meeting was closed at $18.35 \mathrm{pm}$.

Another observation on campaigns was the unnecessary use of excessive power by security forces. On 30 October, 2010, CHADEMA presidential candidate Dr. Wilbroad Slaa closed his campaigns in Mbeya Urban Constituency. After the rally, a crowd of people followed the candidate and blocked the roads something that sounded like a demonstration. The police deployed its force to arrest many people and bombed them heavily. Most people were going back home on foot and whenever people moved in groups they were heavily bombed. This was interpreted by the security officials as unlawful demonstration something which was not the case. The author was also a victim of this situation.

\subsection{Voting}

Voting was done national wide on 31 October, 2010. Broadly speaking, the voting day was done smoothly. However, as noted in the registration process, most registered voters could not vote because of their names to be missing in the PNVR. Yet some voters could not see their pictures in the books and still others their voters' cards number differed with those in the books. As noted earlier, all with these problems were not allowed to vote unnecessarily. This is to the author's view a premeditated strategy. It is interesting to note that early in the morning on 31 October, 2010 at 6.00 am on Tanzania Broad Casting Company (TBC1) the chairman of the National Electoral Commission (NEC) Judge Lewis Makame in his speech on election day declared clearly that all with the problems mentioned above should be allowed to vote. Contrary to that the polling stations' supervisors did not have that direction.

It is crystal clear that this information came late consciously since the NEC knew for sure that problems like those existed in the books. If NEC was having good intention then it would have made the decision to allow those with the problem earlier so that the poll supervisors be directed accordingly. In my contact with several polling stations supervisors on election day, I asked them whether they were informed by the decision to allow all people with such problems to vote. They all said no such information was communicated to them and that they do not act in accordance with information heard from the TV but based on the training they received. This problem was so evident in many polling stations and lots of people were plainly restricted to vote. This problem among other things, resulted to failure of most people to exercise their constitutional right to vote and contributed to the critical problem of low voter turnout in the constituency and ultimately to the national level. It is worth emphasising that while citizen played their role to register, NEC on its part acted as a roadblock for them to exercise their constitutional right to vote.

\subsection{Vote Counting and Declaration of Results}

The last process is vote counting and declaration of results. The counting was done at polling stations and the tallying process proceeded at the central tallying hall. It should be noted that at the station level the exercise went smoothly. However, interesting things were observed in the tallying process. Among other things was the opening of the ballot boxes closed at the polling stations. This is normally against the law unless directed by the court to be so. It can be argued that some of those who might have chances to jeopardise the results can do anything to rig by using this loophole. Yet, another incidence was noted. Two results forms had similar names of polling stations. One was "Shule ya Msingi Mayanga 1 and the second was named "Shuleya Msingi Mayanga". In the two polling stations, the results forms were signed by two different supervisors and different party agents. When it came to tallying, the RO simply decided to take one form which gave relatively more votes to CCM presidential candidate Mr. Jakaya Mrisho Kikwete. The results of the two forms at least for the two parties were as follows:

Table 2. Form 1- Shule ya Msingi Mayanga 1

\begin{tabular}{ccc}
\hline Party & Candidate & Votes \\
\hline CCM & Mr. Jakaya Mrisho Kikwete & 49 \\
CHADEMA & Dr. Wilbroad Slaa Peter & 139
\end{tabular}

Source: Author's observation and compilation, 2010. 
Table 3. Form 2- Shule ya Msingi Mayanga

\begin{tabular}{ccc}
\hline Party & Candidate & Votes \\
\hline CCM & Mr. Jakaya Mrisho Kikwete & 53 \\
CHADEMA & Dr. Wilbroad Slaa Peter & 129
\end{tabular}

Source: Author's observation and compilation, 2010.

As can be seen, form number one is a more formal one since it specifies the number of the stations. There were four stations named Shule ya Msingi Mayanga 1-4. However, the RO decided to fill the second one.

When asked, the computerized tallying specialist said he entered the first already but he had to change after the RO's direction. In the process, the CCM agent was present observing. Unfortunately the CHADEMA agent went out and when he came back and asked him about the two forms he said the agreement was for both forms to be entered and results aggregated. But that was not the case. Clearly, this shows the possibilities of both what I call "Ghost polling stations" and vote rigging. Although the tallying process was computerised, it remained extremely slow and boring. This sparked off feelings among voters that their votes might be stolen or to use recent famous word (kuchakachua kura). A lot of voices and misunderstandings between the NEC and voters emerged to the extent that the police interfered and started bombing voters who were waiting outside the tallying building. In the process of making follow-up of the tallying process, the author's hired car was stoned by angry voters shouting if "Sugu" (Note 24) does not win you won't get out of this building". It was chaos because even the bombs were affecting those of us who were in the tallying hall. This slow process resulted in to chaos not only in the constituency but also in many others like in Arusha, Mbozi West and Ubungo to mention but a few examples. Vote counting and declaration of results were the electoral stages that led to massive election related incidents of violence in the 2010 elections particularly in Mbeya and the whole country in general.

\section{Conclusions}

This article examined actors and processes in the 2010 general elections in Mbeya Urban Constituency. It noted that the election was generally conducted smoothly. All stages of the electoral process were generally well conducted. The level of awareness on the part of citizens in the constituency is particularly commendable. They were attending the campaigns of most parties and candidates on equal basis for them to have informed choice. Apart from poor performance by CCM parliamentary candidate in his two terms of 2000 and 2005 and his massive use of abusive language in his campaigns, this did not change the minds of people against his opponent CHADEMA candidate. The fact that they voted for an alternative party because of the mal-performance of the former leader is a clear indication of high level of civic competence among citizens in the constituency. Additionally, one measure of multiparty democracy is power alternation between parties. Since the inception of multiparty democracy in 1995, power alternation featured well in Mbeya Urban Constituency between the ruling party and the opposing parties. In the 1995 general elections NCCR-MAGEUZI won the constituency and was taken over by CCM in 2000 and 2005 elections. CHADEMA took over CCM in the 2010 general election.

Despite commendable stride towards multiparty democracy in the constituency, more remain to be done. Voter registration, candidate nominations, campaigns, voting, counting and declaration of results were hampered by such problems as skewed laws, weak institutional capacity, incumbency advantage, corruption, abusive language, violence, ghost voters and polling stations and other irregularities. The legal and institutional frameworks that guide multiparty politics in Tanzania are still a systemic problem. Actors such as opposition parties and some civil societies have always been critical to this and have argued for a new constitution that reflects the spirit of democracy. On this ground, the government initiated the process of making a new constitution in early 2012. Stakeholders are, however, sceptical of the process since it is controlled by the ruling party and its government.

\section{References}

Baregu, M. (2003). The State of Political Parties in Tanzania.The African Review: A Journal of African Politics, Development and International Affairs, 29(1\&2), 19-35.

Bratton, M., \& Van de Walle, N. (1997).Democratic Experiments in Africa: Regime Transitions in Comparative Perspective. Cambridge: Cambridge University Press. http://dx.doi.org/10.1017/CBO9781139174657

Chama Cha Mapinduzi (CCM). (1997). The Constitution of Chama Cha Mapinduzi, 1977, CCM's Headquarters. Dodoma, Tanzania. 
Hyden, G. (1999). Top-Down Democratization in Tanzania. Journal of Democracy, 10(4), 142-155. http://dx.doi.org/10.1353/jod.1999.0066

Kamata, N. (2006). Jeshi la Polisi na Ujenzi wa Demokrasia Tanzania. Paper presented in REDET's Training Workshop for Senior Police Officers, Bwawani Hotel, Zanzibar, 13-14 February, 2006.

Liviga, A. (2009). Tanzania: A Bumpy Road to Consolidated Democracy. Eastern Africa Social Science Research Review, XXV (1), 1-42. http://dx.doi.org/10.1353/eas.0.0005

Makulilo, A. B. (2008). Tanzania: A De Facto One Party State? VDM Verlag Dr. Muller Aktiengesellschaft \& Co. Kg, Germany.

Makulilo, A. B. (2009). Independent Electoral Commission in Tanzania: A False Debate? Representation,45(4), 435-453. http://dx.doi.org/10.1080/00344890903257409

Makulilo, A. B. (2010). State -Party and Democracy: Tanzania and Zambia in Comparative Perspective. $\mathrm{PhD}$ Thesis University of Leipzig, Germany.

Mallya, E. T. (2006). Religion and Elections in Tanzania Mainland. In R. S. Mukandala (Eds.), Justice, Rights and Worship: Religion and Politics in Tanzania. Dar es Salaam: E\&D Limited.

Mbeya City Investment Profile. (2010). Retrieved September 15, 2012, from http://www.mbeya.go.tz/index.php?option=com_docman\&task=doc_download\&gid=6\&Itemid=179

National Electoral Commission (NEC). (1996). Report of the National Electoral Commission on the 1995 Presidential and Parliamentary Elections. Dar es Salaam: United Republic of Tanzania, Government Printer.

NEC. (2001). Report of the National Electoral Commission on the 2000 Presidential and Parliamentary and Councillors' Elections. Dar es Salaam: Dar es Salaam University Press.

NEC. (2006). The Report of the National Electoral Commission on the 2005 Presidential, Parliamentary and Councilors' Elections. Dar es Salaam: Dar es Salaam University Press.

NEC. (2010a). Parliamentary and Presidential election results in Mbeya Urban Constituency.

NEC. (2010b). The Report of the National Electoral Commission on the 2010 Presidential and Parliamentary Elections. Retrieved October 20, 2010, from http://www.nec.go.tz

Olukoshi, A. (1998). The Politics of Opposition in Contemporary Africa. Uppsala: Nordiska Afrikainstitutet.

Pinkney, R. (1997). Democracy and Dictatorship in Ghana and Tanzania. London: Macmillan Press Limited. http://dx.doi.org/10.1057/9780230379589

Raphael, C. (2011). Party Institutionalisation in Tanzania: A State Project? VDM Verlag Dr. Muller Aktiengesellschaft \& Co. Kg, Germany.

Shivji, I. G. (2006). Let the People Speak: Tanzania Down the Road to Neo-Liberalism. Codesria Book Series: CODESRIA.

Synovate. (2010). Tanzania Media Election Coverage Weekly Monitoring Report. 11 -17 October 2010, Report No. 20.

Tanzania Election Monitoring Committee (TEMCO). (1997). The Report of the 1995 General Elections in Tanzania. Dar es Salaam: University of Dar es Salaam.

TEMCO. (2001). The Report of the 2000 General Elections in Tanzania. Dar es Salaam: University of Dar es Salaam.

TEMCO. (2006). The Report of the 2005 General Elections in Tanzania. Dar es Salaam: University of Dar es Salaam.

TEMCO. (2010). The Interim Statement for 2010 General Election.

The University of Dar es Salaam Institute of Development Studies (IDS). (2010). Grappling with Corruption in Local Government Elections: A Focus of Arusha, Dar es Salaam, Morogoro, Dodoma, Kilimanjaro, Tanga, and Manyara Regions. Prevention and Combating Corruption Bureau (PCCB) Headquarters, Dar es Salaam, March 2010

United Republic of Tanzania (URT). (1992). The Presidential Commission on Single Party or Multiparty System in Tanzania: Report and Recommendations of the Commission on the Democratic System in Tanzania, (Volume 1). Dare es Salaam: Dar es Salaam University Press. 
URT. Elections (Amendment) Act No. 13 of 1990. Dar es Salaam: Government Printer.

URT. Elections Act, No. 1 of 1985. Dar es Salaam: Government Printer.

URT. (2002). National Population and Housing Census, 2002. Retrieved October 25, 2010, from www.tanzania.go.tz/2002cenus.PDF

URT. Political Parties Act, No. 5 of 1992. Dar es Salaam: Government Printer.

URT. The Constitution of the United Republic of Tanzania,1977. Dar es Salaam: Government Printer.

Whitehead, R. L. (2009). Single Party rule in a Multiparty age: Tanzania in Comparative Perspective. PhD Dissertation: Temple University.

Wunsch, J. S., \& Olowu, D. (1990). The Failure of the Centralized State: Institutions and self-Governance in Africa. Boulder: Westview Press.

\section{Notes}

Note 1. Tanzania is a United Republic after the merger of the two formerly independent states of Tanganyika and Zanzibar on 26 April, 1964.

Note 2. During these elections, the author was part of the Tanzania Election Monitoring Committee (TEMCO) team in Mbeya Urban Constituency in observing the elections.

Note 3. Interview with Mr Joseph Mbilinyi CHADEMA parliamentary candidate, 14 October, 2010, Mbeya; Interview with Mr. Mustafa Haji Kurwa CUF council candidate for Maendeleo ward 30 September, 2010, Mbeya; Interview with Mr Godfrey Davis APPT-MAENDELEO regional party chairman and council candidate for Iyunga ward 11 October, 2010, Mbeya; Interview with Mr. Lwitiko Mwakapesa, District Party Secretary 26 September, 2010 Mbeya; Interview with Mr. Boniface Mwakibinga TADEA regional chairperson, 8 September, 2010, Mbeya.

Note 4. Interview with Mr. Ipyana Mlilo UVCCM Mbeya, 18 October, 2010. In this interview the respondent told the author that he was sent by the party to go to Mbozi West constituency to make sure that CCM wins. The author was interested in the strategy used to achieve that goal. He said that they campaign to the people that they should not vote for opposition because it brings about war and instability and that they are highly supported by the youth who are also pro conflict and war.

Note 5. Interview with Mr. Ipyana Mlilo UVCCM member in Mbeya, 21 December, 2010, Dar es Salaam.

Note 6. The author managed to attend the campaign meeting by Mama Salma Kikwete the first lady with CCM women wing (UWT) on 19 October, 2010 at Benjamin Mkapa's Hall in Mbeya. The caution was given by mama Salma that factions are inimical to the party and they are supposed to build the same house they should there for not fight for blocks. She insisted party members to forget the wounds caused during party nominations and should give hand to the candidate to ensure party's victory.

Note 7. Interview with the District Registration Officer Ms. Elizabeth Kalinga 1 October, 2010, Mbeya City Council.

Note 8 . When asked, the District Registration officer said no prescribed time was given by the NEC headquarters and that they managed to effect only three upgrading exercises in the constituency.

Note 9. My interviews with all participating and non-participating opposition parties in the constituency attest to this stand point: Interview with Mr. Lwitiko Mwakapesa, District Party secretary 26 September 2010 at Uyole-Mbeya; Interview with Mr. Boniface Mwakibinga TADEA regional chairperson 8 September 2010, Mbeya; Interview with Mr. Mwidunda CUF district secretary 24 September 2010, Mbeya; Interview with Mr Godfrey Davis APPT-MAENDELEO council candidate for Iyunga ward 11 October, 2010, Mbeya; Interview with Ms. Emmy Hudson Mwakisole UPDP parliamentary candidate, 15 October, 2010, Mbeya; Interview with Mr. Charles Mwampagana SAU Party Regional Chairman 25 October, 2010, Mbeya; Interview with Mr. Diomon Mwansampeta NCCR-MAGEUZI Regional party Chairman, 25 October, 2010, Mbeya; Interview with Mr. Ezekiel Mwailiteleke UDP Regional Party Secretary 24 October, 2010, Mbeya; Interview with Mr. Moses Mwasubila CHADEMA District Party Publicity secretary 12 October, 2010, Mbeya.

Note 10. Interview with the Returning Officer Dr. Samuel Lazaro 16 October; 2010, Mbeya City Council.

Note 11. Interview with the Prevention and Combat of Corruption Bureau Officer, PCCB Mbeya, 7 October, 2010, Mbeya. 
Note 12. Interview with the State Attorney to the Registrar of Political Parties Southern Highlands Zonal Office, 4 October, 2010, Mbeya.

Note 13. This information was gathered from the interview with political parties and candidates in the constituency at different times. Interview with Mr. Joseph Mbilinyi CHADEMA parliamentary candidate, 14 October, 2010, Mbeya; Interview with Ms. Emmy Hudson Mwakisole UPDP parliamentary candidate, 15 October, 2010, Mbeya; Interview with Mr. Atanas Kapunga CCM council candidate for Itiji Ward, 16 October, 2010; CCM district offices, Mbeya; Interview with Mr. Mustafa Haji Kurwa CUF council candidate for Maendeleo ward 30 September, 2010, Mbeya; Interview with Mr Godfrey Davis APPT-MAENDELEO council candidate for Iyunga ward 11 October, 2010, Mbeya; Interview with Mr. Lwitiko Mwakapesa, District Party secretary 26 September 2010 at Uyole-Mbeya; Interview with Mr. Boniface Mwakibinga TADEA regional chairperson 8 September 2010, Mbeya; Interview with Mr. Mwidunda CUF district secretary 24 September 2010, Mbeya.

Note 14. Interview with Mr. Benson M. Mpesya, CCM parliamentary candidate Mbeya Urban Constituency, 8 October, 2010 at CCM district offices in Mbeya.

Note 15. Interview with Mr. Joseph Mbilinyi, CHADEMA parliamentary candidate, 14 October, 2010, Mbeya.

Note 16. This meeting was held at Stockholm Hotel in Mbeya argued CHADEMA parliamentary candidate Mr. Joseph Mbilinyi.

Note 17. These offices are established by the president using his constitutional powers and its officers appointed by the president who is also a candidate in an election.

Note 18. The 2010 CCM Presidential candidate and the President of the United Republic of Tanzania

Note 19. Interview with Mr. Prince Gwamaka Mwaihojo, CUF parliamentary candidate Mbeya Urban Constituency, 8 October, 2010, Mbeya.

Note 20. Interview with Mr. Aggabo Twalondaga Mwakatobe NCCR-MAGEUZI parliamentary candidate, 25 October, 2010, Mbeya.

Note 21. Interview with Ms. Emmy Hudson Mwakisole UPDP parliamentary candidate, 15 October, 2010, Mbeya.

Note 22. This statement was uttered by one of the CCM's campaign team's members and council candidate in Itiji Ward Mr. Atanas Kapunga on 17 September, 2010.

Note 23. Translated as "CHADEMA parliamentary candidate is a crook, he is too blind to see good things that CCM did for the people. CHADEMA claims that Benson is tired, he sleeps in the parliament. If I am tired would I manage to reproduce children with my wife? He who knows whether I am tired or not is my wife".

Note 24. Nick name of the CHADEMA parliamentary candidate Mr. Joseph Mbilinyi. 